\title{
GRAND UNIFIED THEORY
}

\author{
Erika Stevens
}

T $\mathrm{f}$ the past exists only in its retelling, I'll tell you that I picture her with a Greek hook to her nose. She's maybe a little astigmatic, fond of

her library and matters of state. She's more charming than most but no more murder-prone than her forbears or than having a brotherhusband might make anyone.

That we still argue over her life as much as over her death suggests that she who dies by poison can never be said to have surrendered, much less been bought.

An electromagnetic empress charged with positive binding force can't resist radioactive decay when time catches up. And history is written

by hegemonies of strong force that are often unkind to the smart, charismatic women we might have known as savvy or wily strategic planners-in

the absence of the word whore. Cleopatra is all arrows to me, a vector field of hypotheses to consider. It is not the tabloid-steamy sex

I'm interested in but how she used the binding agents at her disposal, how she wore her agency, and what she thought about linking work and pleasure. 